\title{
Peluang Wirausaha Budidaya Anggrek Dendrobium hybrid
}

\author{
Abd. Rofik \\ Universitas Widya Gama Mahakam Samarinda \\ birudaun83@gmail.com
}

\begin{abstract}
Abstrak
Sektor agribisnis di Indonesia diikuti dengan semakin berkembangnya wirausaha tanaman anggrek. Anggrek memiliki prospek yang cukup baik untuk diusahakan dalam wirausaha tanaman hias karena mempunyai nilai jual yang cukup tinggi dan menjanjikan keuntungan yang besar. Di Indonesia anggrek merupakan tanaman yang mempunyai nilai ekonomis tinggi sehingga peluang pemasaran anggrek sangat potensial baik untuk bunga potong maupun untuk bunga pot. Potensi usaha yang dapat dikembangkan dari tanaman anggrek meliputi; usaha pembibitan (perbanyakan), usaha pembesaran, usaha perdagangan dan ekspor. Selain produk dalam bentuk bunga anggrek, juga dilakukan penjualan produk sampingan dari kegiatan ini berupa pupuk organik cair, media tanam (arang) dan souvenir anggrek.
\end{abstract}

Kata Kunci: Wirausaha, Budidaya, Anggrek Dendrobium 


\section{Jurnal Abdimas Mahakam \\ https://journal.uwgm.ac.id/index.php/abdimasmahakam \\ Online ISSN : 2549-5755 \\ Januari 2018, Vol. 2 No. 1}

\section{Pendahuluan}

Tanaman anggrek dengan segala keunikannya yang memukau, telah menarik perhatian para penggemar tanaman hias sejak 2 abad yang lalu, anggrek dalam penggolongan taksonomi, termasuk dalam family orchidaceae, suatu family yang sangat besar dan bervariasi. Family ini terdiri dari 800 genus dan tidak kurang dari 25.000 spesies. Dahulu para ahli berpendapat bahwa family compastiae yang anggotanya meliputi : azter, zinnia dan chrysanthemum adalah famili yang besar dan sulit diulas, tetapi ternyata orchidaceae ini lebih bervariasi lagi. Persilangan-persilangan dalam famili anggrek mudah terjadi. Persilangan yang pertama terjadi antara 2 spesies clanthe yang dilakukan oleh John Dominy dari Inggris berbunga pada tahun 1856. Keberhasilan persilangan tersebut telah membuka kemungkinan baru yang kemudian berkembang menjadi suatu keunikan yang tidak pernah terjadi dalam hortikultura sebelumnya. Anggrek ternyata dapat disilangkan tidak hanya dengan spesies yang termasuk dalam suatu genus seperti tanaman hias lainnya, tetapi juga dengan genus lainnya, contoh persilangan antara aerides dengan vanda. Banyak orang berpendapat bahwa anggrek adalah tanaman yang sukar tumbuh, membutuhkan alat-alat atau perlengkapan yang mahal serta pemeliharaan yang rumit.

Tanaman anggrek mempunyai banyak habitat di alam seperti, secara terrestrial, epifit, lithofit, semi-aquatik. Di alam bebas kebanyakan anggrek bersifat epifit, hidup menempel pada tumbuhan lainnya, tanpa merugikan tanamanan yang ditumpanginya. Karena sifatnya ini maka pengusahaan anggrek kebanyakan berupa tanaman pot, hanya beberapa jenis vanda arachnis aranda yang ditumbuhkan di tanah.

Anggrek terrestrial hidup di media tanah dan membutuhkan cahaya matahari penuh atau hampur penuh agar tumbuh dan berkembang dengan baik. Untuk mendapatkan hasil yang maksimum sesuai dengan tujuan pemeliharaan, syarat tumbuh yang diinginkan harus dipenuhi.

Perbanyakan tanaman anggrek dilakukan dengan dua cara, yaitu generatif dan vegetatif. Cara generatif dilakukan dengan perbanyakan melalui biji yang didahului dengan penyerbukan bunga. Perbanyakan secara vegetatif dapat dilakukan dengan menanam bagian tubuh dari tanaman itu sendiri dan bagian yang biasa digunakan seperti batang, akar, dan rhizom atau umbi. Perbanyakan secara vegetatif dapat dilakukan dengan cara splitting (pemisahan 


\section{Jurnal Abdimas Mahakam \\ https://journal.uwgm.ac.id/index.php/abdimasmahakam \\ Online ISSN : 2549-5755 \\ Januari 2018, Vol. 2 No. 1}

anakan), pemotongan anak tanaman yang keluar dari batang (stek), dan pemotongan anak tanaman yang keluar dari tangkai bunga (keiki).

\section{Tujuan}

Tujuan dari penyuluhan adalah meningkatkan pengetahuan masyarakat mengenai peluang usaha baru dalam bidang tanaman anggrek dan mampu menjual kepada konsumen yang lebih luas sehingga dapat memberikan keuntungan baik aspek finansial, pengetahuan dan ketrampilan.

\section{Manfaat}

Manfaat yang akan datang dari kegiatan ini adalah dapat menumbuhkan jiwa wirausaha dalam bidang tanaman anggrek.

\section{Metode}

Kegiatan Pengabdian kepada Masyarakat dilaksanakan di Kelurahan Lempake Kecamatan Samarinda Utara. Peserta Pengabdian kepada Masyarakat adalah kelompok masyarakat petani. Metode kegiatan penyuluhan yaitu melalui ceramah dan diskusi.

\section{Hasil dan Pembahasan}

Usaha budidaya tanaman anggrek secara komersial di Indonesia mempunyai prospek yang sangat baik. Kebutuhan pasar domestik masih sangat besar dengan makin banyak event-event yang memanfaatkan anggrek sebagai hiasan utama, khususnya di kota-kota besar. Tiap-tiap fase pertumbuhan anggrek masing-masing mempunyai pangsa pasar sendiri dan juga bernilai jual tinggi.

Kunci keberhasilan pembudidayaan dan membuat tanaman anggrek Dendrobium tetap indah dan cantik salah satunya ditentukan oleh teknik dan intensitas perawatannya. Kebutuhan perawatan anggrek didukung dengan pemilihan jenis dan dosis pupuk yang tepat untuk setiap tahap pertumbuhan dan perkembangan yaitu mulai bibit dalam botolan, kompot (community pot), seedling, remaja dan fase berbunga.

konsumen lebih banyak memburu Dendrobium memiliki variasi warna dan bentuk bunga beragam, sehingga konsumen yang cepat bosan selalu memiliki pilihan. Kelebihan lain dari 


\section{Jurnal Abdimas Mahakam \\ https://journal.uwgm.ac.id/index.php/abdimasmahakam \\ Online ISSN : 2549-5755 \\ Januari 2018, Vol. 2 No. 1}

Dendrobium adalah pemeliharaan yang relativ mudah, sehingga masyarakat awam tidak sulit menikmati keindahannya, sifat yang mudah dan rajin berbunga, bunga mekar bisa bertahan hingga 30 hari serta penanaman di daerah panas justru membuat anggrek Dendrobium tumbuh maksimal.

Anggrek Dendrobium banyak digemari masyarakat karena rajin berbunga dengan warna dan bentuk bunga yang bervariasi dan menarik. Selain itu sering digunakan dalam rangkaian bunga karena memiliki kesegaran yang relatif lama, warna dan bentuk bunganya bervariasi serta tangkainya yang lentur sehingga mudah dibentuk dan produktivitasnya cukup tinggi (Widiastoety, dkk., 2007).

\section{Simpulan dan rekomendasi}

Dari penyuluhan yang telah dilakukan, maka dapat disimpulkan bahwa :

1. Kegiatan ini dapat menambah pengetahuan masyarakat sebagai alternatif peluang usaha baru berupa wirausaha anggrek Dendrobium.

2. Kegiatan ini memberikan kontribusi terhadap masyarakat dalam meningkatkan pendapatan keluarga. 


\section{Jurnal Abdimas Mahakam}

\section{https://journal.uwgm.ac.id/index.php/abdimasmahakam}

Online ISSN : 2549-5755

Januari 2018, Vol. 2 No. 1

\section{Daftar Pustaka}

Gunawan, Livy Winata. 2003. Budidaya Anggrek. Penebar Swadaya. Jakarta. 90 Hal.

Setiawan, Herman. 2002. Usaha Pembesaran Anggrek. Penebar Swadaya. Jakarta. 88 Hal.

Widiastoety D, NinaS, dan Muchtar S. 2010. Potensi Anggrek Dendrobium dalam Meningkatkan Variasi dan Kualitas Anggrek Bunga Potong.Jurnal Litbang Pertanian. 29(3): 101-106 